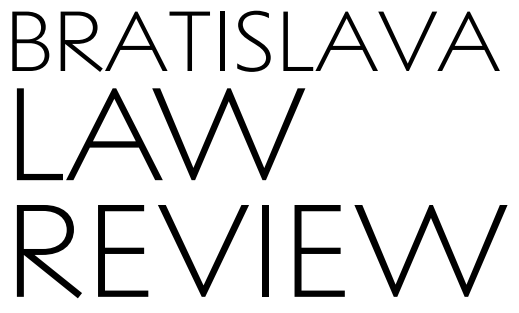

PUBLISHED BY

COMENIUS UNIVERSITY IN BRATISLAVA FACULTY OF LAW

ISSN (print): 2585-7088

ISSN (electronic): 2644-6359

\title{
TOOLBOX OF THE PUBLIC ADMINISTRATION ENTITY. INTERSECTION OF THE PRINCIPLE OF LEGALITY AND ADMINISTRATIVE DISCRETION IN EXERCISING THE REVOCATION OF AN ADMINISTRATIVE DECISION: THE CASE OF LITHUANIA / Simona Bareikytè
}

\author{
Simona Bareikyté \\ PhD. Student \\ Vilnius University, Faculty of Law \\ Saulétekio al. 9 - I rūmai \\ 10222 Vilnius \\ Lithuania \\ simona.bareikyte@tf.vu.lt \\ ORCID: 0000-0002-4502-8619
}

\begin{abstract}
For some, revocation of an administrative decision arises doubts, for others, it is a legal measure ensuring that public administration entities are able to respond to changing circumstances and adopt not only legitimate, but also fair decisions by striking a balance between private and public interests. This paper aims to analyse the choice of Lithuania with respect to the implementation and application of the public administration entities right to revoke its previously adopted administrative decision. In order to achieve this goal, the results of analysis of the role of the principle of legality and administrative discretion in the decisionmaking process, legal regulation of public administration and caselaw are revealed. The analysis will show that there is room for the possible systematisation of the administrative procedures, aiming to ensure that public administration entities are able to respond to the ongoing changes in order to fulfil the objectivities based on which the particular public administration entities were established.
\end{abstract}

Key words: administrative procedure; revocation; legality; administrative discretion; Lithuanian law.

Suggested citation:

Bareikyte S. (2021). Toolbox of the Public Administration Entity. Intersection of the Principle of Legality and Administrative Discretion in Exercising the Revocation of an Administrative Decision: The Case of Lithuania. Bratislava Law Review, 5(2),63-74. https://doi.org/10.46282/blr.2021.5.2.255
Submitted: 09 July 2021 Accepted: 07 October 2021 Published: 30 December 2021

\section{INTRODUCTION}

Public administration entities have the power, in accordance with the requirements of legal acts, to adopt administrative decisions, which have direct legal effects ${ }^{1}$ with respect to those for whom they have been adopted or indirect legal effects on other interested parties. In legal rules-based societies, natural people and legal entities coordinate their actions and activities in accordance with administrative decisions.

\footnotetext{
${ }^{1}$ For instance, to grant a request or benefits, to impose sanctions (disciplinary or service penalties, economic sanctions, fines, or enforcement obligations), to issue permits, licences or certificates which are entitling a natural person or legal entity to engage in certain activities, etc.
} 
Therefore, it is not surprising why people expect from public administration entities not to "change their minds" after adopting administrative decisions. But it is also not surprising why this "expectation" has been denied by accepting the fact that in a dynamic field of public administration, administrative decisions taken by public administration entities could be revoked by the same public administration entities (so-called Revocation of administrative decision $\left.{ }^{2}\right){ }^{3}$

The establishment of the Revocation of administrative decision in a number of legal acts regulating administrative procedures is usually based on the aim to ensure that public administration is flexible enough to be sufficient to respond to changes and that public administration entities are provided with sufficient legal means to adopt not only lawful but also fair administrative decisions having in mind the possibility of errors, changes in circumstances, etc. Given that the Revocation of administrative decision provides an exclusive right to public administration entities to intervene in a legal relationship established where an arbitrariness could be occur, usually the number of safeguards are developed to ensure that the Revocation of administrative decision would be applied only on a legal basis indicated in legal acts, in accordance with a clear and public procedure and after the assessment how it would affect people to whom the revoked administrative decision had been issued, what benefits it brings to the common good.

In Lithuania, unlike in other European countries, ${ }^{4}$ administrative procedures are not codified. Instead, there is variety of special laws, regulating different regulatory fields. No significant changes have been taken in place in legal regulation of public administration since the declaration of Lithuania's independence. But from 2020 November 1 the new version of the Law on Public Administration has been entered into force. From that day, public administration entities in addition to have the power to adopt administrative decisions as well have the power to revoke them by declaring that lawful or unlawful administrative decisions are no longer into force (in Lithuanian: neteko galios). Taking it into account, the one question arises as to whether the aforementioned legal development is the start of the possible essential changes in the administrative decisionmaking process.

This and the significance of the meaning of the Revocation of administrative decision for the relationship among public administration entities and natural and legal people reveals the goal of this article - to analyse the "legal road" of Lithuania with respect to the Revocation of administrative decision. In order to fully achieve the set goal, the following tasks have been set: first, to determine the intersection of the principle of

\footnotetext{
2 The definition "Revocation of administrative decision" is understood as an act in which the public administration entity revokes its own administrative decision. Taking into account the legal situation in Lithuania and assessing the limited scope of this article, this definition covers cases when unlawful or lawful administrative decisions are revoked, and when the legal effects of revoked administrative decisions are considered to have disappeared ex tunc or ex nunc. A more detailed analysis of these cases is needed in the future.

3 This is approved by legal scholars (Schønberg, 2003), Council of Europe (see Recommendation $\mathrm{CM} / \operatorname{Rec}(2007) 7$ of the Committee of Ministers to Member States on Good Administration, S 21 (2007)) and the legislators of the different States (see the Polish Code of Administrative Procedure, Chapter 13 (1960), the Italian Administrative Procedure Act, Chapter IV-bis (1990), the German Administrative Procedure Act, S 48 and 49 (1976), the Spanish Law on Administrative Procedure of the Public Administrations, S 109 (2015), the Austrian General Administrative Procedure Act, S 68 (1991), the Slovenian General Administrative Procedure Act, S 278 (1999), the Croatian General Administrative Procedure Act, S 129 - 131 (2009), etc.) and European Union (Research Network on EU Administrative Law, S III-35 and III-36 (2017). Proposal for a Regulation of the European Parliament and of the Council for an open, efficient and independent European Union administration, S 23 and 24 (2016)).

${ }^{4}$ See ref. 3.
} 
legality and administrative discretion. This is necessary to uncover the general idea of the public administration entities powers and their limitations in Lithuania; second, to analyse the legal context and status quo of the legal regulation regarding the public administration entities power to revoke administrative decisions, in order to determine whether a clear procedure of Revocation of administrative decision is in place; third, to analyse the caselaw regarding the interpretation of presented legal regulation. This is important to understand whether near the legislative rules, there are rules created by case law regarding the right to revoke administrative decisions. The results of these tasks will help without repeating to formulate final conclusions that focus on future prospects.

In order to achieve the goal of this article, mainly historical, descriptive, method of analysis and induction methods were used.

In addition, some clarification should be noted. In order to reveal the meaning of the Revocation of administrative decision (also - concept of administrative discretion), the legal regulations of other countries were used, but it is not the subject of this analysis. Also, the scope of this research is limited to the adoption of the administrative decisions during the provision of administrative services, supervision and implementation of legal acts and administrative decisions, and administration of the provision of public services. ${ }^{5}$ Therefore, the scope of this study does not include the adoption of the normative (regulatory) administrative decisions. This study is also limited to purely internal situations, which means that the analysis of the content of the principle of legality, administrative discretion, and power to revoke the administrative decision is not assessed regarding the implementation of the European Union primary or secondary law.

\section{PRINCIPLE OF LEGALITY AND ADMINISTRATIVE DISCRETION IN DESICION- MAKING PROCESS}

The most important activity of public administration entities is the adoption of administrative decisions that have negative or positive consequences for natural or legal people. It, therefore, becomes extremely important in analysing what standards (principles) are set for the decision-making process in public administration.

Despite the very wide scope of the public administration, the basic principles that all public administration entities must follow when making administrative decisions are recognized and called "general principles" (Dambrauskiene; 2004, p. 145). One of them is the principle of legality, according to which all activities of public administration entities are based, and which is understood as a necessary condition for the consistency of the entire public administration system (Bakaveckas, 2012, pp. 74, 76). This principle is distinct from other legal principles governing public administration, as it contains other principles relevant to the decision-making process and creates a general requirement to adopt administrative decisions in accordance with the requirements indicated in the laws (Bakaveckas, 2012, pp. 74-75). Also, the uniqueness of this principle is reflected in the fact that it directly implements the general principle of public administration that "only what is provided by the law is allowed", which is understood to mean that in the absence of a sufficiently clear legal rules, the public administration entity has no discretion to act in any way.

Having this in mind it is not surprising that the legal doctrine upholds a strict position that public administration entities cannot take any other action without a legal basis, that all actions of the public administration entities must be regulated by laws. It is

\footnotetext{
${ }^{5}$ In respect of the areas of the public administration indicated in the Lithuanian Law on Public Administration, S 6 (1999).
} 
worth mentioning that this doctrinal position is supported by the meaning of other general principles of the public administration "rule of law", which basically means that the activities of public administration entities must be established in accordance with and comply with the legal bases set out in the laws. ${ }^{6}$ This is approved by court. ${ }^{7}$ Also it is in comply with the principle of non-abuse of power, which basically means that public administration entities are prohibited from performing the functions of public administration without the powers of public administration granted in accordance with the procedure established by the law or from making administrative decisions for purposes other than those established by the law. ${ }^{8}$

However, it is not possible to regulate all situations. Keeping this in mind, scholars began to think more about the importance of administrative discretion in administrative decision-making process. Unfortunately, there are not many studies analysing which concept of administrative discretion in public administration prevails (Andruškevičius and Paškevičiene, 2011, p. 227). It is limited to declarative reflections that, for instance, administrative discretion is a tool for dealing with situations that are not fully resolved, or that the public administration entities should be left with as little administrative discretion as possible, thus avoiding arbitrariness and (or) abuse. However, neither the doctrine, nor the case-law, nor the legislator has denied the using the administrative discretion in administrative decision-making process.

As the definition of administrative discretion is not provided by the law, its concept is revealed in the case law. According to the case law, administrative discretion is understood as the power which gives the administrative entity a degree of discretion in enabling it to choose the most appropriate action from among the various options available. ${ }^{9}$ This position is essentially in line with the French and German concepts of administrative discretion (Seerden, 2018, pp. 27, 90), which is understood as a choice between several legally established alternatives in the administrative decision-making process and assessment of law and facts.

To sum up, in Lithuania, the decision-making process is based on the principle of legality, which ensures the application of the basic principle of all public administration system - "only what is provided by the law is allowed". Administrative discretion does not provide a legal basis for adopting administrative decision, which is not provided by the law. Administrative discretion which confers a degree of freedom in the administrative decision-making process is limited to availability to choose one of the legal possible ways indicated in law and to assess both facts and law. It means that any shortcomings in the legal regulation of administrative procedures essentially eliminate the adoption of any possible or needed administrative decision ad hoc. The fact that the choice of issuing administrative decision is exclusively limited by the legal regulation established by law in legal doctrine is considered to be one of the mainly shortcomings of the quality of public administration (Andruškevičius, 2008, p. 309).

Taking into consideration, it is therefore necessary to determine whether this doctrinal position will be confirmed by the existing legal regulation of the public administration.

\footnotetext{
${ }^{6}$ Lithuanian Law on Public Administration, S 3, part 4 (1999).

7 The Republic of Lithuania, the Supreme Administrative Court of Lithuania, A261-706/2014 (14 May 2014).

${ }^{8}$ Lithuanian Law on Public Administration, S 3, part 8 (1999).

9 The Republic of Lithuania, the Supreme Administrative Court of Lithuania, A ${ }^{415}$-2203/2006 (18 December 2006), the Republic of Lithuania, the Supreme Administrative Court of Lithuania, A-2995-492/2018 (13 November 2018).
} 


\section{LEGAL "CONTEX" AND THE STATUS QUO}

In Lithuania, public administration is regulated by: (i) the Constitution of the Republic of Lithuania; (ii) the primary and secondary European Union legislation ${ }^{10}$; (iii) Part 4 of Article 72 of the Law on the Constitutional Court of the Republic of Lithuania (regarding the enforcement of administrative decisions taken during the implementation of anti-constitutional legislation (provisions); (iv) the Law on Public Administration (hereinafter referred to as the "LPA"), which establishes the principles of public administration, areas of public administration, systems of public administration entities, administrative procedures, main provisions for the supervision of the activities of economic entities, and guarantees the right of individuals to appeal against acts, omissions or administrative decisions, as well as the right to the examination of requests and complaints of individuals, and establishes other rights and obligations of people and entities in the field of public administration; ( $v$ ) special laws that govern specific regulatory areas ${ }^{11}$ and (vi) the secondary legislation (in Lithuanian: poịstatyminiai teises aktai) that details the legal regulation established in the LPA and special laws. ${ }^{12}$

Even though administrative procedures are not codified, the prevailing position is that public administration is regulated on the basis of the legal regulatory model of lex generalis (LPA) and lex specialis (special laws), with the view that the public administration first shall be carried out using the LPA. However, in legal reality, legal regulation indicated in special laws is preferred, in compliance with the principle of lex specialis derogat legi generali. Even though this problematic regulatory situation is not the subject of this article, the analysis of the Revocation of administrative decision in public administration is performed, considering presented prevailing distinction.

\subsection{Lex Generalis}

On 1 January 2007, the Error Correction Procedure was established in Article 35 of the LPA. In general - the Error Correction Procedure did not allow the public administration entity to revoke its administrative decision, because by using this procedure public administration entities were enabled to correct only typographical or technical errors. Mainly the most important aspect of the Error Correction Procedure is that it was applied only in the case of "administrative procedure", which in Lithuania is understood as an administrative appeal against an act (omission) of a public administration entity. ${ }^{13}$ It means that this procedure was not applied to the administrative decision-making process. This is the reason why until 1 November 2020 there were no general legal provisions indicated in the LPA governing the procedure and grounds on which the public administration entity may lawfully revoke its administrative decision.

Following the abovementioned date, together with Article 15 under which the Error Correction Procedure is regulated, Article 16 of the LPA came into force. Currently, the public administration entity may declare invalid (the result is the same as to revoke

\footnotetext{
${ }^{10}$ Lithuanian Constitutional Act concerning the Membership of the Republic of Lithuania in the European Union, S 2 (2004).

11 For instance, the Law on the Legal Status of Aliens (2004), Law on Tax Administration (2004), Law on Competition (1999), Law on Competition (2012), Law on the Legal Protection of Personal Data (1996), Law on the Legal Protection of Personal Data (2000), Law on the Legal Protection of Personal Data (2003), Law on the Legal Protection of Personal Data (2008).

12 For instance, Rules for the Examination of Applications and Complaints and the Servicing of Persons in Public Administrative Entities (2007).

${ }^{13}$ The concept of the administrative procedure is not the object of this article, but the conception which is stated in the LPA is criticised by legal scholars.
} 
administrative decision) previously adopted illegal or lawful (only if this is permitted under other law) administrative decision, or lawful conditional administrative decision, meaning when the person did not fulfil established conditions within the established period of time. In compliance with Article 17, the public administration entity has the power to declare invalid all administrative decisions which have been made as a result of an illegal influence or fraud. Mainly the most important change regarding the abovementioned legal changes is that legislator started to regulate the administrative decision-making process.

It is needed to note that Article 16 of the LAP is of a declarative nature and it does not contain any indication of how the right to declare invalid issued administrative decision should be exercised. There is no time limit, no indicators regarding to which decisions (in a substantive matter) this right could be applied and to which could not, no procedural provisions or indicators about the procedure during which the administrative decision under Article 16 of the LAP (in some cases in conjunction with Article 17 of the LAP) has to be taken. It is not clear how the right to revoke administrative decision has to be exercised (whether for each administrative decision or not, mandatory or optional part of the procedure). Also, considering the legal regulation of other States, it is not clear if the act "to declare invalid" must always end up with the revocation of the previously adopted administrative decision alone, or it may end up with the revocation of the previously adopted administrative decision and the adoption of a new one.

To sum up, Article 16 of the LAP (in some cases in conjunction with Article 17 of the LAP) raises doubts about what is the value ground of the legislator, who decided to adopt such legal regulation, whether the objectives which were sought to be achieved could be actually achieved having in mind the uncovered shortcomings in legal regulation.

\subsection{Lex Specialis}

First of all, it should be noted that in the special laws, unlike the LPA, the right to revoke a previously adopted administrative decision was legitimised long before. ${ }^{14}$

But the analysis of the special laws reveals that the legal regulation is selective: there are regulatory areas in which the Revocation of administrative decision is established, and there are regulatory areas in which the Revocation of administrative decision is not established. Legal norms indicated in special laws give a wide degree of administrative discretion to the public administration entities to assess facts in respect of special legal regulation of specific regulatory field.

In cases where the right to revoke a previously adopted administrative decision is regulated for the final administrative decisions ${ }^{15}$ (Schønberg, 2003), there are no provisions regarding the time limit and provisions of what procedure should be used in order to use this power. Also, there is a lack of procedural provisions, which would be helpful in revealing what steps the public administration entity should make in order to revoke previously adopted administrative decision. In addition, not all grounds (for instance, legal error, factual error, misconduct of the party, etc.) are established as well.

\footnotetext{
${ }^{14}$ For instance, the Law on Construction (1996), Law on Construction (2001), Law on Local Self-Government of the Republic of Lithuania (1994), Law on Land Reform (1991), Law on State Supervision of Territorial Planning and Construction (2013), Law on the Bank of Lithuania (1994), Law on Banks (2004), Law on Central Credit Unions (2000), Law on Credit Unions (1995), Financial Instruments Law on Markets (2007), Law on Collective Investment Undertakings for Informed Investors (2013), Statute of the Internal Service (2003), Law on the Protection of Persons and Property (2004), Law on the Control of Weapons and Ammunition (2002), Law on Animal Breeding (1994), Law on the Legal Status of Aliens (2004), Law on Competition (1999), Law on the Control of the Circulation of Civil Pyrotechnic Articles (2002).

15 So called temporary completed decisions.
} 
In other cases where the right to revoke a previously adopted administrative decision is regulated for the administrative decisions which have continuous temporal dimension (Schønberg, 2003), the law sets out specific and clear grounds for the use of analysed right, but there is a lack of the provisions of the time limit which is important in ensuring legal certainty.

After evaluating the preliminary conclusions of Part 3.1 and evaluating the results of the analysis presented in this Part, it can be stated that the LPA and special laws itself do not constitute a harmonized legal regulation regarding the Revocation of administrative decisions.

It is worth considering that the courts have the possibility, to a certain extent, to fill in legal gaps, left by the legislators, ad hoc by applying the law. ${ }^{16}$ The judicial ad hoc elimination of legal gaps presupposes the formation of a uniform case law in resolving a certain category of cases. The court precedents can be later substantially amended or otherwise adjusted by the legislator (or another competent legislative entity), regulating certain public relations by law (or another legal act) and thus eliminating the respective legal gap not already by ad hoc means, but with a future-oriented legal regulation of a general nature. ${ }^{17}$

Because the procedures are the heart of any activity carried out by public administration entities, firstly it should be pointed that it is obvious that rules based on case law cannot replace or change rules indicated in the legal act. But at the same time courts' precedents are not only inspirations for the changes in legal regulation, but also are mandatory for the public administration entities in similar or analogous situations. Having this in mind it becomes important to see if the courts' precedents regarding the Revocation of administrative decision procedure have been created.

\section{CASE LAW: STILL IN A "LEGAL IMPASSE"?}

For the beginning it is worth stressing out that the Supreme Administrative Court of Lithuania has gradually relaxed the interpretation of the law with regard to the Revocation of administrative decision. Initially, the position was that the public administration entity itself could not revoke its administrative decision, which has legal consequences for the persons concerned, but was adopted in violation of the applicable legal norms. ${ }^{18}$ It was later acknowledged that there was no direct prohibition on the public administration entity itself to revoke an administrative decision. ${ }^{19}$ Until finally, the Supreme Administrative Court of Lithuania clarified that the principle of legality of decisions taken by public administration entities in the field of public administration means that a public administration entity may not revoke its decisions unless such possibility is provided by special laws applicable to its regulatory area. ${ }^{20}$

However, this mitigating position was limited to that that courts has been following the legal precedent on the basis of which, the public administration entity cannot revoke its own administrative decision, if there is no legal norm indicated that ${ }^{21}$

\footnotetext{
16 The Republic of Lithuania, the Constitutional Court of the Republic of Lithuania, 09/2008 (29 November 2010).

17 The Republic of Lithuania, the Constitutional Court of the Republic of Lithuania, 34/03 (8 August 2006).

${ }^{18}$ The Republic of Lithuania, the Supreme Administrative Court of Lithuania, A2-161/2005 (4 February 2005).

${ }^{19}$ The Republic of Lithuania, the Supreme Administrative Court of Lithuania, A756-35/2010 (1 February 2010).

20 The Republic of Lithuania, the Supreme Administrative Court of Lithuania, A602-227/2012 (12 March 2012).

${ }^{21}$ For instance, the Republic of Lithuania, the Supreme Administrative Court of Lithuania, A602-1356/2012 (3

May 2012), the Republic of Lithuania, the Supreme Administrative Court of Lithuania, A143-79/2013 (29
} 
But such adjudicating actually does not lead anywhere ${ }^{22}$, if the legal regulation is not changed. The fact that this is acknowledged by the court is proved by certain indications in case law revealing the advantages of the Revocation of the administrative decisions and, in certain cases, the necessity for it. Firstly, when courts found that the factual situation has changed since the administrative decision was taken, it indicates to the parties that it is the ground for the public administration entity to revoke an administrative decision and adopt a new one. This explanation is not based on a specific legal provision, ${ }^{23}$ but only on court's interpretation about what actions public administration entity should take.

Secondly, there are cases when even with the conclusion that the public administration entity had no the power to revoke a previously adopted administrative decision, at the same time court expressed an opinion outside this conclusion (orbiter dictum). In these types of cases, the Supreme Administrative Court of Lithuania formulated the future test which defines what public administration entity should assess in order to revoke a previously adopted administrative decision: public administration entity should assess the situation in the context of the principle of legal certainty, to determine that the legitimate expectations will not be violated, and in the case of a violation of the legitimate expectations, to assess whether the revocation of the administrative decision will not unreasonably negate one of the competing interests private or public.

Turning to the procedures, it is worth noting that the court takes a strict view that the Revocation of administrative decisions must be carried out in accordance with all the essential administrative decision-making procedures laid down in special laws. ${ }^{24}$ In legal doctrine this is called the principle of parallelism of the procedure (Cliza, M. C). Having this in mind, the principal stages of this type of procedure can be identified (see Table 1).

In respect to the preliminary conclusions regarding the selective legal regulation regarding the procedure of the revocation of administrative decisions, this could be the inspiration for the legislator to systematize legal regulation regarding Revocation of administrative decisions.

\footnotetext{
January 2013), the Republic of Lithuania, the Supreme Administrative Court of Lithuania, A3277-525/2018 (7 February 2018), the Republic of Lithuania, the Supreme Administrative Court of Lithuania, eA-934-492/2019 (2 October 2019), the Republic of Lithuania, the Supreme Administrative Court of Lithuania, eA-935-492/2019 (29 October 2019).

${ }_{22}$ One of the cases highlighted the legal limitations of administrative procedures: the Central Electoral Commission, in accordance with the 2016 December 4 ruling of the Supreme Court of Lithuania, which found that the political leader of the party and the responsible persons had carried out fraudulent bookkeeping, reassessed these new facts and revoked previous administrative decisions, which was issued 2005-2007 and by which the political party was awarded state budget grants. Court resolved the dispute in a formal way, formally stating that the public administration entity had acted ultra vires by revoking its own administrative decisions, because there was not any legal basis for it. Court did not assess the public administration's arguments on the need to revoke its own administrative decisions (the Republic of Lithuania, the Supreme Administrative Court of Lithuania, eR-2-442/2019 (17 April 2019)).

${ }^{23}$ For instance, the Republic of Lithuania, the Supreme Administrative Court of Lithuania, $A^{602}-1865 / 2013$ (2 December 2013), the Republic of Lithuania, the Supreme Administrative Court of Lithuania, eA-1055-602/2018 (14 November 2018), the Republic of Lithuania, the Supreme Administrative Court of Lithuania, eA-687602/2019 (13 November 2019)

${ }^{24}$ The Republic of Lithuania, the Supreme Administrative Court of Lithuania, A525-2380/2011 (27 June 2011), the Republic of Lithuania, the Supreme Administrative Court of Lithuania, A602-151/2012 (8 November 2012), the Republic of Lithuania, the Supreme Administrative Court of Lithuania, A525-560/2014 (19 February 2014).
} 


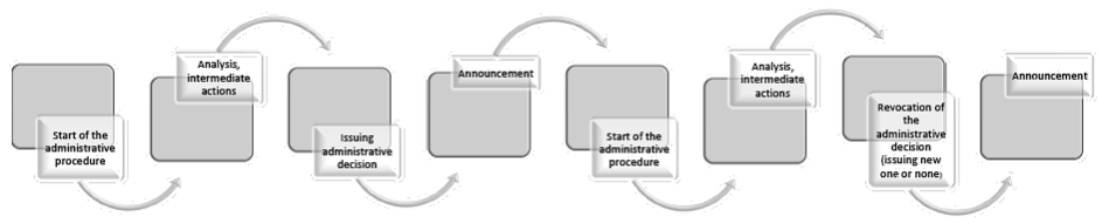

Table 1

Taking this into consideration and the fact that there is no case-law regarding Article 16 and 17 of the LAP so far, instead of the preliminary conclusions there are some remarks regarding the future developments. Adoption of Article 16 of the LAP has the potential to influence the Supreme Administrative Court of Lithuania to modify its caselaw so that, despite only the general provision of Article 16 of the LAP, which does not take precedence over norms established by special laws, the public administration entities would be able to revoke administrative decisions. But, if the predominance of principle of legality and formal adjudicating continue, the legal impasse regarding the revocation of administrative decisions will continue.

\section{CONCLUSIONS}

Lithuanian legal regulation regulating the right to revoke a previously adopted administrative decision is still selective and fragmented, legal rules do not interact with each other, so there is the absent of the consistent revoked administrative decisionmaking procedure. Dominance of the principle of legality in public administration precludes administrative courts from legitimizing administrative decisions which are made in respond to the changes and the unregulated legal situations. Because the Lithuanian administrative decision-making process is subject to a strict adherence to the principle of legality, this eliminates any possibility of adopting an administrative decision only on the basis of administrative discretion. In order to ensure such strict standard, comprehensive and detailed legal regulation, with a clear and public procedure, is necessary. Otherwise, only the formal requirement to follow the legal regulation has the possibility to hinder the resolution of problems arising in the public administration and the adoption of fair administrative decisions, which also undermines trust in the public administration.

\section{BIBLIOGRAPHY:}

Andruškevičius, A. (2008). Administracinè teisè: bendrieji teorijos klausimai, valdymo akty institutas, ginčo santykiu jurisprudenciniai aspektai. Registrų centras.

Andruškevičius, A. and Paškevičiene, L. (2011). Viešojo administravimo teisiniai pagrindai: mokomoji knyga. Registrų centras.

Bakaveckas, A. (2012). Administracinè teisé: teorija ir praktika. I dalis. Leidykla "Mes."

Dambrauskiene; G. (2004). Lietuvos teises pagrindai. Justitia.

Schønberg, S. J. (2003). Legitimate expectations in administrative law. Oxford University Press.

Seerden, R. J. G. H. (Ed.). (2018). Comparative Administrative Law. Administrative Law of the European Union, Its Member States and United States. (4th ed.). Intersentia.

Cliza, M. C. Revocation of administrative act. 
Austria, General Administrative Procedure Act (1991).

Croatia, General Administrative Procedure Act (2009).

Germany, Administrative Procedure Act (1976).

Italy, Administrative Procedure Act (1990).

Lithuania, Law on Land Reform (1991).

Lithuania, Constitution of the Republic of Lithuania (1992).

Lithuania, Law on the Constitutional Court of the Republic of Lithuania (1993).

Lithuania, Law on Animal Breeding (1994).

Lithuania, Law on the Bank of Lithuania (1994).

Lithuania, Law on Local Self-Government of the Republic of Lithuania (1994).

Lithuania, Law on Credit Unions (1995).

Lithuania, Law on Construction (1996).

Lithuania, Law on the Legal Protection of Personal Data (1996).

Lithuania, Law on Competition (1999).

Lithuania, Law on Public Administration (1999).

Lithuania, Law on Central Credit Unions (2000).

Lithuania, Law on the Legal Protection of Personal Data (2000).

Lithuania, Law on Construction (2001).

Lithuania, Law on the Control of Weapons and Ammunition (2002).

Lithuania, Law on the Control of the Circulation of Civil Pyrotechnic Articles (2002).

Lithuania, Law on the Legal Protection of Personal Data (2003).

Lithuania, Statute of the Internal Service (2003).

Lithuania, Constitutional Act concerning the Membership of the Republic of Lithuania in the European Union, (2004).

Lithuania, Law on Banks (2004).

Lithuania, Law on the Legal Status of Aliens (2004).

Lithuania, Law on the Protection of Persons and Property (2004).

Lithuania, Law on Tax Administration (2004).

Lithuania, Financial Instruments Law on Markets (2007).

Lithuania, Rules for the Examination of Applications and Complaints and the Servicing of Persons in Public Administrative Entities (2007).

Lithuania, Law on the Legal Protection of Personal Data (2008).

Lithuania, Law on Competition (2012).

Lithuania, Law on Collective Investment Undertakings for Informed Investors (2013).

Lithuania, Law on State Supervision of Territorial Planning and Construction (2013).

Poland, Code of Administrative Procedure (1960).

Spain, Law on Administrative Procedure of the Public Administrations (2015).

Slovenia, General Administrative Procedure Act (1999).

Republic of Lithuania, Constitutional Court of the Republic of Lithuania, 34/03 (8 August 2006).

Lithuania, Constitutional Court of the Republic of Lithuania, 09/2008 (29 November 2010).

Lithuania, Supreme Administrative Court of Lithuania, A415-2203/2006 (18 December 2006).

Lithuania, the Supreme Administrative Court of Lithuania, A2-161/2005 (4 February 2005).

Lithuania, the Supreme Administrative Court of Lithuania, A756-35/2010 (1 February 2010).

Lithuania, the Supreme Administrative Court of Lithuania, A525-2380/2011 (27 June 2011). 
Lithuania, the Supreme Administrative Court of Lithuania, A602-1356/2012 (3 May 2012).

Lithuania, the Supreme Administrative Court of Lithuania, A602-227/2012 (12 March 2012).

Lithuania, the Supreme Administrative Court of Lithuania, A602-151/2012 (8 November 2012).

Lithuania, the Supreme Administrative Court of Lithuania, A143-79/2013 (29 January 2013).

Lithuania, Supreme Administrative Court of Lithuania, A602-1865/2013 (2 December 2013).

Lithuania, the Supreme Administrative Court of Lithuania, A525-560/2014 (19 February 2014).

Lithuania, Supreme Administrative Court of Lithuania, A261-706/2014 (14 May 2014).

Lithuania, the Supreme Administrative Court of Lithuania, A3277-525/2018 (7 February 2018).

Lithuania, Supreme Administrative Court of Lithuania, A-2995-492/2018 (13 November 2018).

Lithuania, Supreme Administrative Court of Lithuania, eA-1055-602/2018 (14 November 2018).

Lithuania, Supreme Administrative Court of Lithuania, eR-2-442/2019 (17 April 2019).

Lithuania, Supreme Administrative Court of Lithuania, eA-934-492/2019 (2 October 2019).

Lithuania, Supreme Administrative Court of Lithuania, eA-935-492/2019 (29 October 2019).

Lithuania, Supreme Administrative Court of Lithuania, eA-687-602/2019 (13 November 2019).

Research Network on EU Administrative Law. (2017). ReNEUAL Model Rules on EU Administrative Procedure (H. C. H. Hofmann, J.-P. Schneider, J. Ziller, J.-B. Auby, P. Craig, D. Curtin, G. della Cananea, D.-U. Galetta, J. Mendes, O. Mir, U. Stelkens, and M. Wierzbowsk (Eds.)). Oxford University Press.

http://www.reneual.eu/images/Home/ReNEUAL--Model-Rules-update2015_rules-only-2017.PDF

Recommendation CM/Rec(2007)7 of the Committee of Ministers to Member States on Good Administration (2007).

Proposal for a Regulation of the European Parliament and of the Council for an open, efficient and independent European Union administration (2016). 
